УДК 635.21 DOI 10.31210/visnyk2018.03.04

(C) 2018

Семенов А. О., кандидат фізико-математичних наук,

Кожушко Г. М., доктор технічних наук,

Сахно Т. В., доктор хімічних наук

Полтавський університет економіки і торгівлі

\title{
ЕФЕКТИВНІСТЬ ПРОРОСТАННЯ НАСІННЯ РІПАКУ ПРИ ПЕРЕДПОСІВНОМУ ОПРОМІНЕННІ ЙОГО УФ-ВИПРОМІНЕННЯМ РІЗНОГО СПЕКТРАЛЬНОГО СКЛАДУ
}

\section{Рецензент - доктор сільськогосподарських наук Г. О. Бірта}

У роботі досліджено вплив трьох різних областей C (200-280 нм), B (280-320 нм) ma A (320м400 нм) ультрафіолетового опромінення насіння. Встановлено, щзо УФ-випромінювання, незалежно від спектрального діапазону, позитивно впливає на біологічні прочеси: енергія проростання, здатність до проростання та схожість насіння для області $C$ більша на 5-11\%, у порівнянні з УФ областями А і B, за однакових доз УФ-опромінювання.

Ключові слова: УФ-опромінення, доза опромінення, передпосівна обробка насіння, енергія проростання, схожість, проиеси розвитку.

Постановка проблеми. Одне 3 основних завдань АПК - збільшення кількості та якості продукції рослинництва. Для вирішення даної проблеми вчені та фахівці сільського господарства постійно вдосконалюють методи і технічні засоби для підвищення продуктивності рослинної продукції $[1,9,10]$.

Значної уваги щодо стимулювання зростання та підвищення стійкості рослин до зовнішніх чинників і збільшення врожайності сільськогосподарських культур заслуговує використання оптичного випромінювання - передпосівна обробка насіння сільськогосподарських культур ультрафіолетовим випроміненням [14, 15, 21, 22].

Аналіз останніх досліджень i публікацій, у яких започатковано розв'язання проблеми. Одним з ефективних способів підвищення якості посівного матеріалу $є$ вплив на насіння фізичними факторами, які, в порівнянні з хімічними, не забруднюють навколишнього середовища i не мають післядії. Для цього в сільськогосподарській практиці використовують різноманітні прийоми передпосівної обробки насіння: ультрафіолетове опромінювання [15], обігрів [7], вплив іонізуючих гамма-променів [20], електричних [17] і магнітних полів [2, 18] та електромагнітних випромінювань [12].

Незважаючи на короткий період дослідження передпосівної обробки насіння УФ-опроміненням, уже опубліковано значну кількість праць [8, $14,15]$.

Передпосівне УФ-опромінення насіння підвищує енергію проростання та схожість $[8,24], \epsilon$ стимулятором ростових процесів, підвищує стресостійкість рослин [3], знезаражує насіння від хвороботворних мікроорганізмів $[13,26]$, що дозволяє зменшувати застосування отрутохімікатів, підвищує якість продукції та ії врожайність $[1,9,10]$.

Так, у роботі [25] було досліджено вплив УФВ на проростання 19 видів рослин. I той факт, що тільки два із трьох сортів томатів були більш чутливими до дози опромінення, підтверджує, що для кожного сорту окремо повинна бути підібрана найбільш ефективна доза. Авторами роботи [21] показано, що при опроміненні УФ-В протягом 15 хвилин, уповільнюється проростання та зменшується ріст розсади. В інших роботах представлено результати щодо опромінювання УФ-В сої [19], різних сортів квасолі [23].

При передпосівному УФ-опромінюванні насіння величина енергії, спектральний склад і час обробки є різними для кожної культури, тому вибір режиму обробки вимагає детального дослідження та диференційованого підходу.

Як показав аналіз літературних джерел, автори не завжди наводять інформацію щодо параметрів проведення експерименту, і підтвердити отримані результати або спростувати їх є можливим.

Мета дослідження - вивчення передпосівного впливу трьох різних областей С (200-280 нм), В (280-320 нм) та А (320-400 нм) ультрафіолетового опромінення насіння ріпаку на біологічні процеси (енергія проростання, здатність до проростання та схожість) у лабораторних умовах.

Матеріали та умови досліджень. Енергію проростання, здатність до проростання та схожість насіння ріпаку визначали в лабораторних умовах за методиками згідно з $[6,11]$. 


\section{СІЛЬСЬКЕ ГОСПОДАРСТВО. РОСЛИННИЦТВО}

Порівнювали ці показники для насіння, опроміненого в різних енергетичних областях $\mathrm{A}, \mathrm{B}, \mathrm{C}$ ультрафіолетового випромінювання за однакових доз опромінення 120 Дж/м², з контрольними зразками (без опромінення). Під енергією проростання розуміють відсоткову кількість пророслого насіння за 72 години, здатністю до проростання - відсоткову кількість пророслого насіння за 120 годин, схожістю насіння - відсоткову кількість пророслого насіння ріпаку за 7 діб.

Проби для проведення дослідження відбирали iз партії ріпаку відповідно до вимог [19]. Для проведення експериментальних досліджень із отриманих проб було відраховано 200 насінин для контрольного зразку та по 200 зернин для опромінення в різних енергетичних областях уьтрафіолетового спектру випромінювання.

Насіння розкладалось на кількох шарах зволо- женого фільтрувального паперу в чашках Петрі (рис. 1) і витримувались в термостаті за температури $7 \pm 2{ }^{0} \mathrm{C}$ протягом доби. Далі охолоджені зразки насіння, крім контрольного, опромінювали в різних енергетичних областях ультрафіолетового випромінювання при дозах 120 Дж/м².

Для опромінення застосовували УФ лампи різних типів, що здатні випромінювати в різних енергетичних областях ультрафіолетового спектру $[5,16]$ :

1. Область УФ-А: лампа ЛУФ 65/80, потужністю 80 Вт.

2. Область УФ-В: лампа ЛЭ-30 Вт, потужністю 30 Вт.

3. Область УФ-С: лампа ZW20D15W, потужністю 20 Вт.

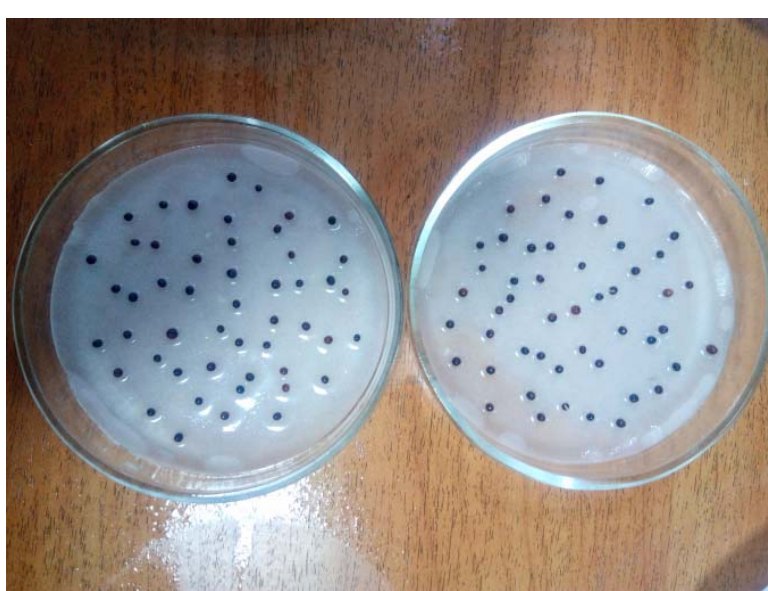

a)

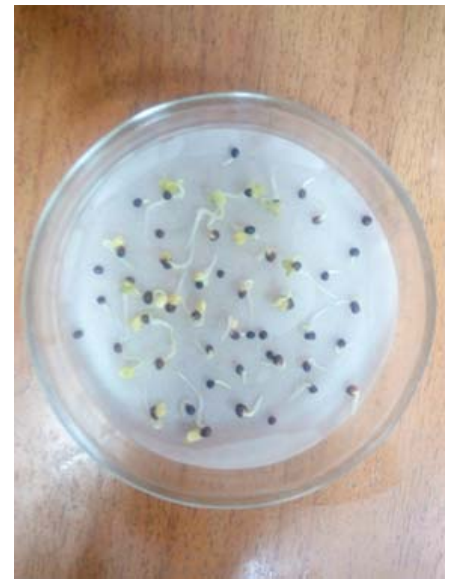

б)

Рис. 1. Насіння ріпаку, розкладене на зволоженому фільтрувальному папері в чашках Петрі: а) до опромінення, б) опромінене та проросле (енергія проростання).

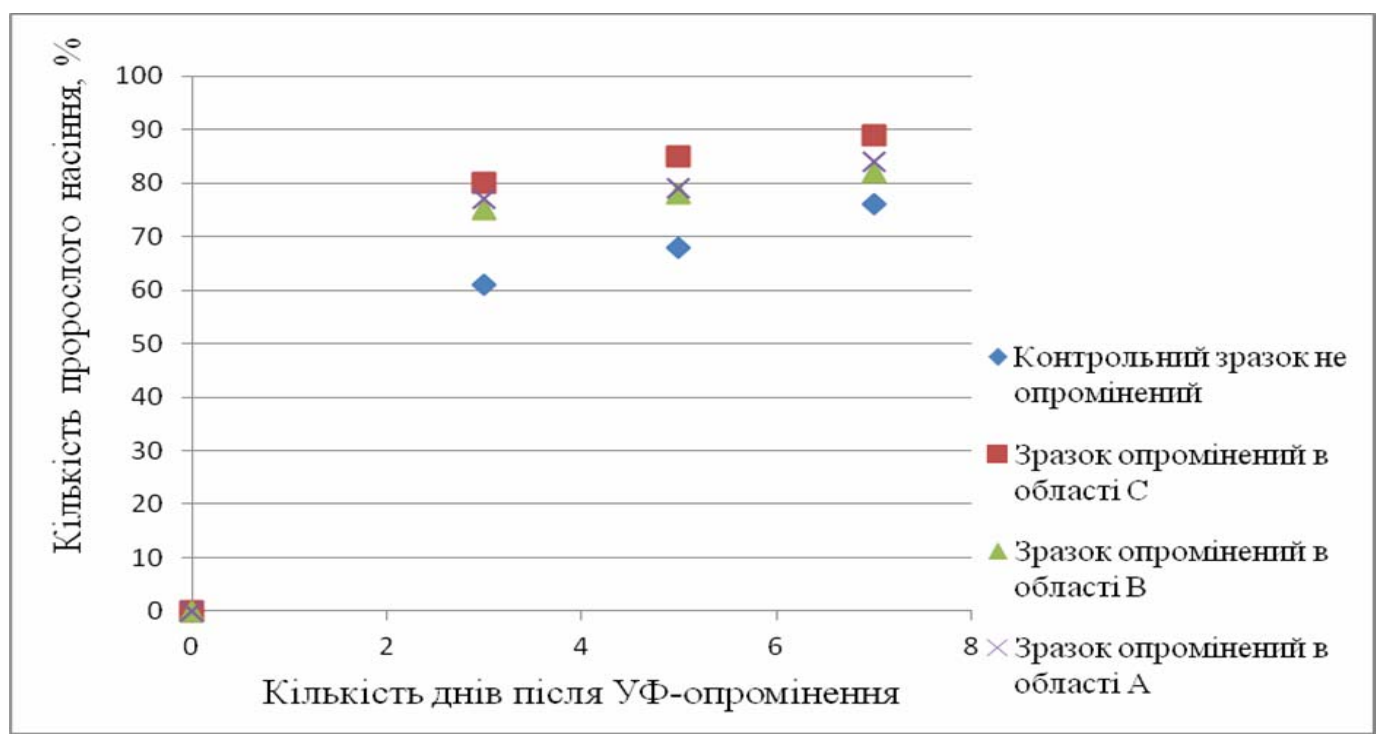

Рис. 2. Залежність кількості пророслого насіння від часу проростання 
СІЛЬСЬКЕ ГОСПОДАРСТВО. РОСЛИННИЦТВО

1. Енерхія проростання, здатність до проростання та схожість опромінених в областях УФ-С, УФ-В та УФ-А дозою 120 Дж/ $^{2}$ та контрольного зразків насіння ріпаку

\begin{tabular}{|c|c|c|c|c|}
\hline & $\begin{array}{c}\text { Контрольний } \\
\text { зразок }\end{array}$ & $\begin{array}{c}\text { Зразок, опроміне- } \\
\text { ний в області } \\
\text { УФ-С }\end{array}$ & $\begin{array}{c}\text { Зразок, опроміне- } \\
\text { ний в області } \\
\text { УФ-В }\end{array}$ & $\begin{array}{c}\text { Зразок, опроміне- } \\
\text { ний в області } \\
\text { УФ-А }\end{array}$ \\
\hline $\begin{array}{c}\text { Енергія } \\
\text { проростання, \% }\end{array}$ & 61 & 80 & 75 & 77 \\
\hline $\begin{array}{c}\text { Відсоток } \\
\text { збільшення, \% }\end{array}$ & - & 31,1 & 23,0 & 26,2 \\
\hline $\begin{array}{c}\text { Здатність до } \\
\text { проростання, \% }\end{array}$ & 68 & 85 & 78 & 79 \\
\hline $\begin{array}{c}\text { Відсоток } \\
\text { збільшення, \% }\end{array}$ & - & 25,0 & 14,7 & 16,2 \\
\hline Схожість, \% & 76 & 89 & 82 & 10,5 \\
\hline $\begin{array}{c}\text { Відсоток } \\
\text { збільшення, \% }\end{array}$ & - & 17,1 & 7,9 & 84 \\
\hline
\end{tabular}

Відстань від лампи до зразків насіння становила 0,25 м. Вимірювання доз УФ-опромінення в різних енергетичних областях ультрафіолетового діапазону здійснювали за допомогою радіометра «Тензор-31» з використанням методики [4].

Опромінені і контрольні зразки насіння пророщували в чашках Петрі за температури повітря $25 \pm 2{ }^{0} \mathrm{C}$ (рис. 2.)

Результати дослідження наведені на рис. 2 та зведені в табл. 1.

Результати досліджень. Результати дослідження енергії проростання насіння ріпаку в залежності від енергетичної дози ультрафіолетового опромінення в областях А, В, С показують, що (табл. 1):

- енергія проростання збільшується, в порівнянні $з$ контрольним зразком, на 31,1 \% для області С, на 23\% - для області В збільшується, на $26,2 \%$ - для області А;

- здатність до проростання збільшується, в порівнянні 3 контрольним зразком, на 25,0 \% для області С, на 14,7 \% - для області В, на 16,2 \% для області $\mathrm{A}$;

- схожість збільшується, в порівнянні з контрольним зразком, на $17,1 \%$ для області $\mathrm{C}$, на 7,9 \% - для області В, на 10,5 \% - для області А.
Висновки. Таким чином, проведені дослідження енергії проростання, здатності до проростання та схожості насіння ріпаку показали, що УФ-опромінення в різних енергетичних областях A, B, C при дозах 120 Дж/м² позитивно впливає на насіння ріпаку, оскільки збільшується енергія проростання (на 23-31\%), здатність до проростання (на 14-25\%) і схожість (на 8-17\%).

Крім того, як показали дослідження, за однакових доз УФ-опромінювання енергія проростання для області С більша на 5-8 \%, у порівнянні з УФ областями А і В. Здатність до проростання для області С більша на 9-11\%, а схожість для області C більша, в порівнянні з областю В, на 9,2 \%, а в порівняні з областю А - на 6,6.

Порівнюючи дію енергетичних областей різних УФ-діапазонів на передпосівне опромінення насіння ріпаку, можна стверджувати, що УФвипромінювання, незалежно від спектрального діапазону, позитивно впливає на енергію проростання, здатність до проростання та схожість рослин.

У подальших дослідженнях планується провести експериментальні роботи по визначенню впливу УФ-випромінення енергетичних облас-

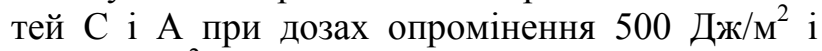
1000 Дж/м ${ }^{2}$ на енергію проростання та схожість насіння ріпаку.

\section{БІБЛІОГРАФІЯ}

1. Антоненко О. Ф. Вплив строків сівби та мікродобрив на розвиток рослин ріпаку озимого в умовах правобережного лісостепу України / О. Ф. Антоненко, Савчук Ю. М. // Вісник ЖНАЕУ. -2016 . - № 1 (53). - T. 1. - C. 87.

2. Бобрышев Ф. И. Влияние магнитных полей на посевные качества семян и продуктивность зерновых культур / Ф. И. Бобрышев, В. М. Редькин, Г. П. Стародубцева, Ш. Ж. Габриелян // Сб. науч. тр.: Пути повышения урожайности 
с.-х. культур. - Ставрополь: Ставропольская ГСХА. - 1995. - С. 33-36.

3. Викулов С. В. Влияние предпосевного облучения семян ультрафиолетом на стрессовоустойчивость проростков кукурузы / С. В. Викулов, Ю. В. Нечаева // Вестник ТГУ. - 2005. T.10. - В. 1. - C. 20-21.

4. Джерела ультрафіолетового випромінювання : методика виконання вимірювань параметрів ультрафіолетового випромінювання. МВУ 11-038-2007 / ННЦ «Інститут метрології». Харків, 2007. - 33 с.

5. Дослідження та розробка вдосконалених конструкцій ультрафіолетових джерел випромінювання для установок фотохімічної i фотобіологічної дії : звіт про НДР (заключ.) : №1 від 01 січня 2011 р. / ВНЗ Укоопспілки "Полтавський університет економіки і торгівлі" ; кер. Кожушко Г. М. ; виконав. : Семенов А. О. [та ін.]. - Полтава, 2015. - 306 с. - №ДР 0112 U007433. - Інв. № 0715U003750.

6. Зерно. Методы определения знергии проростання и способности проростания : ГОСТ 10968-88. - [Чинний від 01-07-1988]. - М. : Стандартинформ, 2009. - 4 с. - (Межгосударственный стандарт).

7. Исаев A. В. Исследование влияния степени неравномерности нагрева семян рапса в ЭМП СВЧ на их энергию прорастания и всхожесть / А. В. Исаев, А. В. Бастрон, В. С. Яхонтова // Вестн. КрасГАУ. - 2016. - № 4. - С. 131-137.

8. Кондратьева Н. П. Компактная светодиодная ультрафиолетовая облучательная установка для предпосевной обработки семян хвойных растений / Н. П. Кондратьева, Н. В. Духтанова, М. Г. Краснолуцкая, В. М. Литвинова, Р. Г. Большин // Вестник ВИЭСХ. - 2017. № 2 (27). - С. 62-69.

9. Кукса Ю.А. Залежність урожайності ріпаку ярого від норм висіву, строків і способів сівби в умовах Північного Степу / Ю. А. Кукса, I. Б. Комарова // Вісник аграрної науки. - 2017. № 8. - C. 32-36.

10. Лавриненко Ю. О. Вплив структурних показників на урожайність насіння ріпаку озимого залежно від строків сівби та норм висіву в Південному Степу України / Ю. О. Лавриненко, А. М. Влащук, Л. В. Шапарь. // Наукові доповіді Національного університету біоресурсів і природокористування України. - 2016. - № 5. - Режим доступу: http://nbuv.gov.ua/UJRN/Nd_2016_5_16.

11. Насіння сільськогосподарських культур. Методи визначення якості : ДСТУ-4138-2002. [Чинний від 01-01-2004] - К. : Держспоживстан- дарт України, 2003. - 173 с. - (Державний стандарт України).

12. Петровський О. М. Технологія передпосівної стимуляції насіння високочастотним електромагнітним полем / О. М. Петровський // Восточно-Европейский журнал передовых технологий. - 2013. - № 6/5. - С. 45-50.

13. Рогожин Ю. В. Технология предпосевного УФ-облучения зерен пшеницы / Ю. В. Рогожин, В. В. Рогожин // Вестник Алтайского государственного аграрного университета. - 2013. № 6 (104). - C. 9-14.

14. Сафаралихонов А. Б. Действие экологических факторов высокогорья и ултрафиолетового облучения семян на рост, транспирацию и активность эндогенных регуляторов роста растений : дис. канд. биолог. наук : 03.02 .08 Душанбе. - 2018. - 134 с.

15. Семенов А. О. Аналіз ролі УФ-випромінювання на розвиток і продуктивність різних культур / А. О. Семенов, Т. В. Сахно, Г. М. Кожушко // Світлотехніка та електроенергетика. - 2017. № 2. - C. 3-16.

16. Семенов А. О. Безозонні бактерицидні лампи для установок фотохімічної і фотобіологічної дії / А. О. Семенов, Г. М. Кожушко, Л. В. Баля // Технологический аудит и резервы производства. - 2015. - № 4/1 (24). - С. 4-7.

17. Усенко С. М. Розрядні процеси в зерновій масі під дією сильного електричного поля імпульсного струму / С. М. Усенко, О. В. Науменко // Енергетика і автоматика. - 2017. - №2. C. $108-115$.

18. De Souza A. Improvement of the seed germination, growth and yield of onion plants by extremely low frequencynon-uniform magnetic fields / A. De Souza, D. Garcia, L. Sueiro, F. Gilart // Scientia Horticulturae. - 2014. -V. 176. - P. 63-69.

19. Liua Bing. Effects of enhanced UV-B radiation on seed growth characteristic sand yield components in soybean Field / Bing Liua, Xiao-bing Liua, Yan-Sheng Lia, S. J. Herbertca // Crops Research. - 2013. - V. 154. - P. 158-163.

20. Majeed $A$. Gamma irradiation i: effect on germination and general growth characteristics of plants-a review / Abdul Majeed, Zahir Muhammad, Rehman Ullah and Hazrat Ali // Pak. J. Bot. - 2018. - 50(6). - P. 2449-2453.

21. Mariz-Ponte N. Moderate UV-A supplementation benefits tomato seed and seedling invigoration: a contribution to the use of UV in seed technology / N. Mariz-Ponte, R. J. Mendes, S. Sario, P. Melo, C. Santos // Scientia Horticulturae. - 2018. V. 235. - P. 357-366. 


\section{СІЛЬСЬКЕ ГОСПОДАРСТВО. РОСЛИННИЦТВО}

22. Neelamegam R. UV-C Irradiation Effect on Seed Germination, Seedling Growth and Productivity of Groundnut (Arachis hypogaea L.) / R. Neelamegam, T. Sutha // Int. J. Curr. Microbiol. App. Sci. - 2015. - № 4 (8). - P. 430-443.

23. Rajendiran $K$. In vitro seed germination and Growth of Three Varieties of Black Gram after U1traviolet-B Radiation / K. Rajendiran, K. Thiruvarasan, R. Vijayalakshmi // Int J Appl Sci Biotechnol. - 2016 - V. 4(1). - P. 117-129.

24. Rupiasih N. Nyoman. Effect of UV-C radiation and hypergravity on germination, growth and content chlorophyll of wheat seedlings / Rupiasih N. Nyoman. // AIP Conference ProceedingsAIP Conference Proceeding. - 2016. - V. 1719 (1). - P. 030035-030035.6.

25. Sugimoto K. Seed germination under UV-B irradiation / K. Sugimoto // Bull. Minamikyushu Univ. - 2013. - V. 43. - A: 1-9.

26. Susana de Sousa Araújo, Stefania Paparella, Daniele Dondi, Antonio Bentivoglio, Daniela Carbonera, and Alma Balestrazzi Advantages and Challenges in Seed Technology// Front Plant Sci. 2016; 7: 646 .

\section{ANNOTATION}

Semenov A. O., Kozhushko G. M., Sakhno T. V. Efficiency of germination of seeds in pre-sowing irradiation by its UV radiation of different spectral composition.

One of the main tasks of the agricultural complex is to increase the quantity and quality of crop production. Great interest in stimulating growth and increasing the resistance of plants to external factors and increasing the productivity of agricultural crops is the use of optical radiation - pre-sowing processing of seeds of crops by ultraviolet radiation.

The effect of three different regions C (200-280 $\mathrm{nm}), \mathrm{B}(280-320 \mathrm{~nm})$ and A $(320-400 \mathrm{~nm})$ of ultraviolet irradiation of seeds was investigated. It is established that UV irradiation irrespective of the spectral range positively affects biological processes: germination energy, germination capacity and seed germination.

The energy of germination, the capacity to germinate and the germination of seeds were determined in laboratory conditions. These indices were compared for seeds irradiated in different energy regions $\mathrm{A}, \mathrm{B}, \mathrm{C}$ of ultraviolet radiation at the same radiation dose of $120 \mathrm{~J} / \mathrm{m}^{2}$ with control samples (without irra- diation).

Investigations of germination energy, germination capacity and seed germination showed that UV irradiation in different energy regions $\mathrm{A}, \mathrm{B}, \mathrm{C}$ at doses of $120 \mathrm{~J} / \mathrm{m}^{2}$ positively affects rape seeds, as the germination energy increases by $23-31 \%$, the capacity to sprouting by $14-25 \%$, and the similarity increases by $8-17 \%$.

In addition, studies at similar doses of UV irradiation show that the germination energy for the $\mathrm{C}$ region is $5-8 \%$ higher in comparison with the UV regions $\mathrm{A}$ and $\mathrm{B}$, while the germination capacity for the $\mathrm{C}$ region is greater by $9-11 \%$, and the similarity for region $\mathrm{C}$ is large by $9.2 \%$ compared with region $\mathrm{B}$, and by 6.6 in comparison with region $\mathrm{A}$.

Comparing the effect of the energy regions of different UV ranges on pre-sowing seed irradiation, it can be stated that UV irradiation irrespective of the spectral range positively affects the germination energy, germination capacity and seed germination.

Key words: UV irradiation, dose of irradiation, pre-sowing seed treatment, germination energy, germination, developmental processes. 